\title{
Two new species of leucosiid crabs (Decapoda: Brachyura) from the Ryukyu Islands, Japan.
}

\section{Tohru Naruse \& Peter K. L. Ng}

\begin{abstract}
Two new species of leucosiid crabs of the genera Alox and Ebalia are described. Alox uru, new species, is distinguished from all eight congeners by the shape of the carapace. Alox rugosum is perhaps most similar to the new species, but Alox uru differs in its carapace shape and the distally swollen male first gonopod. Alox zalion too has distally swollen male first gonopod, but $A$. uru differs from $A$. zalion in having the male first gonopod distally spinose. Ebalia stellaris, new species, is distinguished from $E$. humilis by the characters of the carapace and the cheliped. Ebalia stellaris can be also differentiated from Nursia species by a combination of carapacial characters - lack of dorsal ridge, a salient junction of anterolateral and posterolateral margins, and a distinctly wider carapace.
\end{abstract}

\section{Introduction}

The leucosiid crab fauna of the Ryukyu Islands is not well known. Sakai (2004) listed 99 species of leucosiid crabs from Japan, 21 species of which are exclusively or commonly recorded from the Ryukyus. Considering the lower latitude of the Ryukyu Islands and its more tropical climate, with more extensive reefs, a more diversified leucosiid fauna is to be expected. Indeed, recent studies have discovered several new species and new records (Takeda \& Nakasone, 1991; Takeda, 1995; Komatsu \& Takeda, 1999; Marumura \& Takeda, 2004).

In the course of the faunal survey of Brachyura of the Ryukyu Islands, two new species of leucosiid crabs were obtained from Nakagusuku Bay, Okinawa Island. One new species belongs to the genus Alox Tan \& $\mathrm{Ng}, 1995$, and the other to Ebalia Leach, 1817.

Specimens are deposited in the Natural History Museum and Institute, Chiba, Japan (CBM) and the National Science Museum, Tokyo, Japan (NSMT). The abbreviations $\mathrm{CL}, \mathrm{CW}, \mathrm{G} 1$, and G2 are used for the carapace length, carapace width, male first gonopod, and male second gonopod, respectively.

\section{Taxonomy}

Leucosiidae

Alox Tan \& Ng, 1995

Alox uru, new species

(Figs. 1a, 2)

Material examined.- Holotype. Male, CL $4.4 \mathrm{~mm}$, CW $5.8 \mathrm{~mm}$, CBM-ZC 8906, off Minami-Ukibaru Island, Nakagusuku Bay, Ryukyu Islands, Japan $\left(26^{\circ} 18.066^{\prime} \mathrm{N}\right.$, $127^{\circ} 58.460^{\prime} \mathrm{E}$, depths of $3 \mathrm{~m}$ ), coll. T. Naruse \& Y. Matsuo, SCUBA + dredging, 20 Dec. 2005.

Description of holotype.- Carapace (Figs. 1a, 2a) subtriangular, CW 1.32 times CL. Dorsal surface rough, frontal, branchial, intestinal regions covered with low mushroom-like tubercles; median keel wide, laterally sloping gradually, transversely forming concave curve on midway to cardiac region, with a pair of bumps across intestinal region, bumps rounded, as high as frontal region; intestinal region rounded posteriorly, embossed by lateral deep grooves; branchial region shallowly concave, dish-like, externally surrounded by low, broad rim. Front produced anteriorly, upturned in frontal view, 
divided into two rounded, raised lobes by deep, short fissure. Anterolateral margin nearly straight, slightly concave posteriorly, lacking hepatic lobe and fissures; posterolateral margins subparallel, more or less straight but indented inwards at right angles at about two-thirds length of margin; posterior margin visible in dorsal view, medially concave, produced posteriorly beyond lateral expansion. Epistome narrow, buccal cavern reaching imaginary line joining infraorbital margins. Subhepatic region with blunt lobe directed antero-laterally. Antennule well developed, basal segment fully occupying fossae when closed.

Third maxilliped (Fig. 2b) with broad exopod, as wide as ischium, distally rounded, reaching beyond proximal half of merus; ischium rectangular, inner margin about twice as long as that of merus; merus with sharp apex.

Chelipeds (Fig. 1a) subequal, surfaces rough; merus stout, short, about threefourths of chela, anterior margin widely concave; chela (Fig. 2c, d) high, palm with low granules on proximal outer to dorsal surfaces; immovable finger slightly longer than palm, high, proximal height about threequarters of palm, tapering gradually towards sharp tip which curves inwards and backwards, distal two-thirds of inside of ventral margin lined with granules; movable finger slightly longer than dorsal margin of palm, flat, gently curving inwards and backwards; cutting edges of both fingers with sparse, low, acute teeth.

Ambulatory legs (Fig. 2e) stout, short, covered with large granules except for posterior surfaces of meri, dactyli terminating in sharp, incurving claw.

Abdomen (including telson) (Fig. 2f) hastate; first, second segments short, first segment mostly hidden by posterior carapace margin with only distal-lateral angles visible; third to fifth segments completely fused, proximal angle of third segment produced outwards, third to fifth segments twice as long as sixth segment; sixth segment subtrapezoidal, as long as telson.
G1 (Fig. 2g, h) slightly sinuous, outer margin concave subproximally, subdistally, not tapering gradually, distal half swollen, with both dorsal, ventral surfaces covered with short spines, tip pointed, directed outwards. G2 (Fig. 2i, j) short, with spoonshaped tip.

Coloration.-Alox uru, new species, is uniformly ivory in life, thus hardly discernable from the dead coral and rubble.

Habitat.- Alox uru was collected at depths of 3-6 $\mathrm{m}$ in back-reef moat filled with branches of dead corals. The place is also a cultivation area for seaweed, Cladosiphon okamuranus (Chordariaceae), an aquaculturally important species there.

Distribution.- Known only from Nakagusuku Bay, Ryukyu Islands, Japan.

Etymology.- The name of the new species derives from the Ryukyuan language "uru" (pebbles composed of broken pieces of corals), alluding to its uru-like appearance. The name is used as a noun in apposition.

Remarks.- The genus Alox was established by Tan \& Ng (1995) during their revision of the genus Oreophorus Rüppell, 1830, for species which have the basal segment of the antennule fully occupying the fossae when retracted, a distinctive pattern of carapacial grooves and the presence of mushroom-like granules on the dorsal surface of the carapace. They recognized eight species: three species originally placed in Oreophorus, one in Tlos Adams \& White, 1849, and four new species. Alox uru, new species, can be distinguished from all its congeners by the shape of the carapace, viz. the protruding frontal region with a narrow base, almost straight anterolateral margin, the position of the junction between anterolateral and posterolateral margins being relatively more posterior in position, and the prominent indentation of the posterolateral margin. Alox rugosum (Stimpson, 1858) is probably most similar to the new species in the general shape of the carapace, but Alox uru can easily be differentiated from A. rugosum by the absence of the hepatic protrusion 
(vs. with distinct hepatic protrusion in $A$. rugosum), more strongly produced posterior margin of the carapace and the intestinal region (vs. gently produced in $A$. rugosum), relatively shorter movable finger of the chela (slightly longer than dorsal margin of the palm vs. distinctly longer than dorsal margin of the palm), and the distal half of the G1 being swollen and with both the dorsal and ventral surfaces covered with short spines (vs. distal half of the G1 with of constant width, not covered by spines in $A$. rugosum). In its distally swollen $\mathrm{G} 1, A$. uru is similar to A. zalion Tan \& Ng, 1995, but the former differs in that the distal part of the G1 is densely covered by spines (vs. sparsely covered by setae in $A$. zalion).

Ebalia Leach, 1817

Ebalia stellaris, new species (Figs. 1b, 3)

Material examined.- Holotype. Ovigerous female, CL $2.4 \mathrm{~mm}$, CW $3.6 \mathrm{~mm}$, CBM-ZC 8907, west of Ukibaru Island, Nakagusuku Bay, Ryukyu Islands, Japan $\left(26^{\circ} 18.062^{\prime} \mathrm{N}, 127^{\circ} 58.463\right.$ 'E, depths of 16 $\mathrm{m})$, coll. T. Naruse \& Y. Matsuo, SCUBA + dredging, 20 Dec. 2005.

Comparative material.-Ebalia humilis Takeda, 1977: 1 ovigerous female, CL 2.8 mm, CW $3.4 \mathrm{~mm}$, NSMT-Cr. 5489, holotye, depth of $45 \mathrm{~m}$, st. 15, Ogasawara Islands, Japan, 15 Jun. 1976, coll. M. Takeda \& M. Imajima; 2 juvenile males, 1 female, CL 3.2 $\mathrm{mm}$, CW $3.9 \mathrm{~mm}, 1$ juvenile female, NSMTCr. 5490, paratype, st. 8, Ogasawara Islands, Japan.

Description of female holotype.Carapace (Figs. 1b, 3a) subrhomboidal, CW 1.5 times CL, with pairs of humps on margins. Dorsal surface medially convex, covered with tiny tubercles, without distinct ridges, regions ill-defined. Front deflexed downwards, with triangular margin, frontal region convex dorsally, sloping posteriorly, gastric region with a pair of humps, cardiac region with a smaller hump medially, intesti- nal region triangular, produced posteriorly beyond posterior margin of carapace, branchial region sloping towards margins, slightly concave just inside margins. Anterolateral margin with concave anterior part with small hump on subhepatic region, posterior part produced, junction with posterolateral margin produced, acute, represents greatest width of carapace; posterolateral margin with a large blunt hump on posterior two-fifths. Epistome reduced, anterior margin of buccal cavern reaching imaginary line joining infraorbital margins. Antennule short, basal segments filling inner part of orbit. Eye well developed.

Third maxilliped (Fig. 3b) with broad exopod, as wide as ischium, distal end reaching distal third of merus; merus slightly shorter than ischium, with rounded apex.

Chelipeds (Fig. 3c) symmetrical, surfaces except for fingers covered by tiny tubercles; merus as long as chela, tubercles of distal half larger than other parts of cheliped, anterior margin bearing a small hump medially, posterior margin lined with four rounded teeth; chela with moderately swollen palm, lower margin convex; finger straight, slightly directed downwards, immovable finger as long as palm, movable finger longer than palm; cutting edges lined with small, sharp teeth, no gape when closed.

Ambulatory legs (Fig. 3d) slender, short, meri to propodi granulose, dactyli long, incurving.

Abdomen (Fig. 3e) wide, third to sixth segments completely fused, but incomplete sutures still visible.

Coloration.- Ebalia stellaris, new species, is creamy white in life, with a pair of light khaki rings, each of which surrounds the gastric hump.

Habitat.-Ebalia stellaris was collected at depths of $16 \mathrm{~m}$ with very fine sandy substratum.

Distribution.- Known only from Nakagusuku Bay, Ryukyu Islands, Japan.

Etymology.- From the Latin "stellaris" meaning star-shaped, alluding to the shape 
of the carapace.

Remarks. - The genus Ebalia (type species: Ebalia bryerii Leach, 1817, a junior subjective synonym of Cancer tumefactus Montagu, 1808) currently contains more than 70 species, but its taxonomy is far from stable. Ihle (1918) already indicated that careful studies of the genus would probably lead to their separation into several genera. Serène \& Soh (1976) also recognized its heterogeneity and commented "Ebalia is probably not represented in the Indo-Pacific region" (Serène \& Soh, 1976: 9). This issue needs to be revised in the future. Among highly variable members in terms of outer morphology, the carapace as well as the cheliped of E. humilis Takeda, 1977 are most similar to those of $E$. stellaris, new species. Ebalia stellaris, however, can be distinguished from $E$. humilis by clearer convexities on the dorsal surface of the carapace, with covered with microscopically granules (vs. lower convexities without microscopically granules in $E$. humilis), larger subhepatic and posterolateral humps (vs. humps much smaller in E. humilis), wider carapace (1.50 times CL vs. $1.21-1.22$ times $\mathrm{CL}$ ), and four rounded teeth of the posterior margin of the chelied merus (vs. 3 acute teeth in $E$. humilis) (present study; Takeda, 1977: Figs. 2A, B, 3B-D).

The taxonomy of the genus Nursia Leach, 1817, is also unstable. Ihle (1918) divided Nursia into four groups (A-D) by the formation of the dorsal ridges of the carapace. Serène \& Soh (1976) considered that real Nursia should be limited for Ihle's group $\mathrm{A}$, and the remaining groups be transferred to other existing or new genera. They, however, did not formally do so. This problem was discussed in Komatsu \& Takeda (1999) (also see Tan \& Ng, 1993) but as yet, the genus has not been revised. Recently, Komatsu \& Takeda (2003) transferred two species previously placed in Nursia ( $N$. cornigera Nobili, 1905, and $N$. jousseaumei Nobili, 1905) to a new genus Nobiliella Komatsu \& Takeda, 2003. The actual identity of the type species, Nursia hardwickii Leach, 1817, is also not very clear. It is supposedly a junior subjective synonym of Nursia lar (Fabricius, 1793), but this name also has two other synonyms, Parthenope lar Weber, 1795 (nomen nudum) and Parthenope lar Fabricius, 1798. In the Zoological Museum of the University of Copenhagen in Denmark are type specimens labelled as Parthenope lar Fabricius, 1798 , which are identical to what is today known as Nursia lar (Fabricius, 1793) (second author, unpublished data). Presumably, Fabricius (1798) had decided that what he had named as Cancer lar in 1793 may be better accommodated in Parthenope and renamed it as a new species. This is not surprising as Nursia lar does superficially look like many parthenopid species. The name by Weber (1795) was based on Fabricius' (1798) manuscript which was not yet published at that time.

Ebalia stellaris, new species, has an intermediate appearance that straddles the current members of Ihle's (1918) groups A and D. Superficially, E. stellaris belongs to Ihle's (1918) group D, as the species lacks any ridge on the dorsal surface of the carapace. The new species, however, differs from the members of group D (N. phylloides Ihle, 1918 and $N$. dimorpha Balss, 1915) in possessing rounded large and small humps on middle of posterolateral margin and subhepatic region, respectively (vs. absent), a transversely produced acute junction of anterolateral and posterolateral margins (vs. rounded, bilobed in $N$. phylloides and blunt in $N$. dimorpha), and the presence of small hump on middle of the anterior margin of the chelipedal merus (see Ihle, 1918: Fig. 135; Balss, 1915: Figs. 8, 9).

Ebalia stellaris is also similar to species of Ihle's (1918) group A, such as N. lar (Fabricius, 1793), N. plicata (Herbst, 1804), $N$. minor (Miers, 1879) and $N$. rhomboidalis (Miers, 1879), in possessing a laterally salient junction of the anterolateral and posterolateral margins and the carapace width (defined as the maximum width at the midpoint of the carapace length) being distinctly 


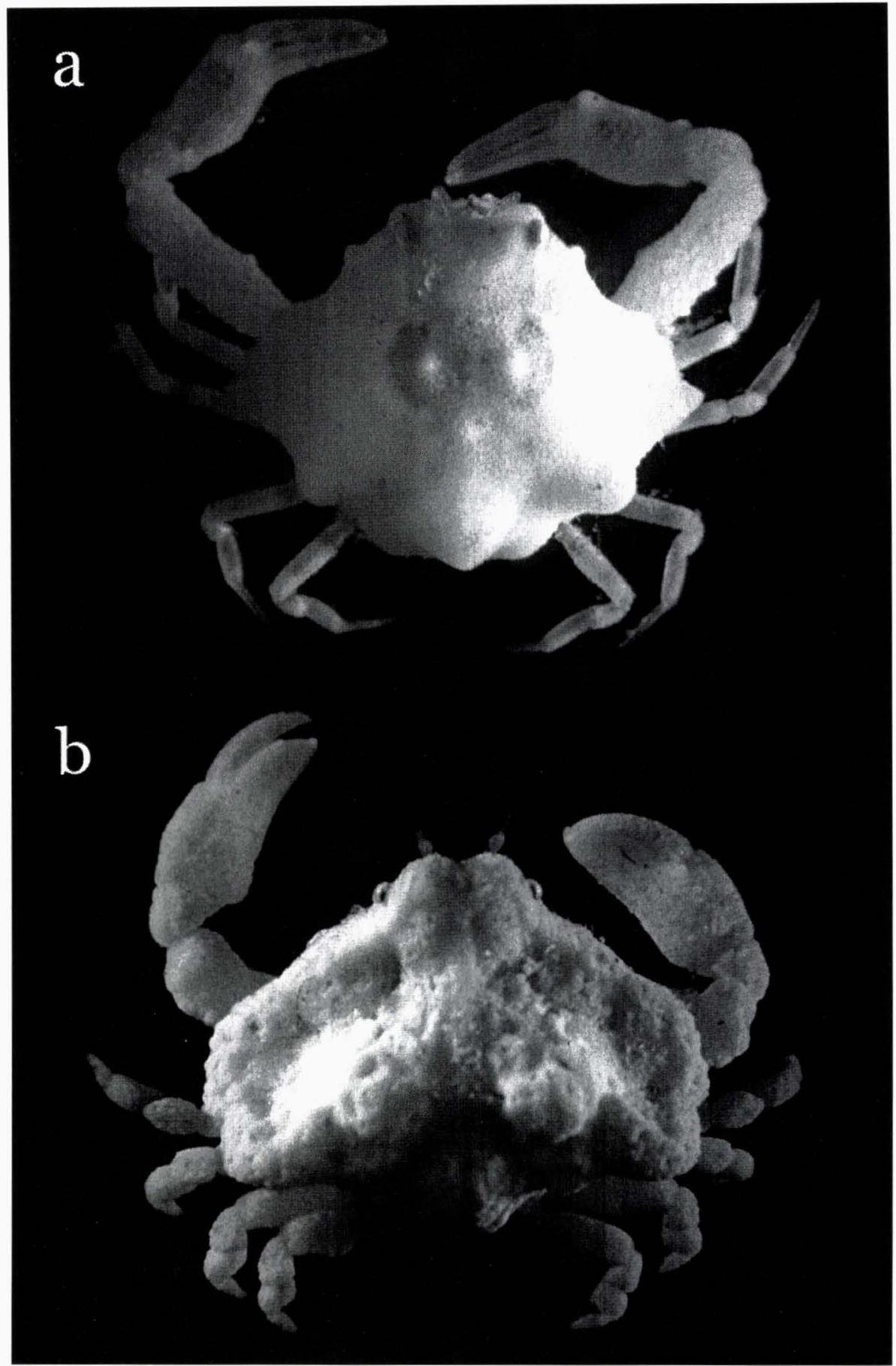

Fig. 1. Alox uru, new species and Ebalia stellaris, new species.

a, A. uru, male holotype, CW $5.8 \mathrm{~mm}$, CBM-ZC 8906; b, E. stellaris, female holotype, CW $3.6 \mathrm{~mm}$, CBM-ZC 8907. 


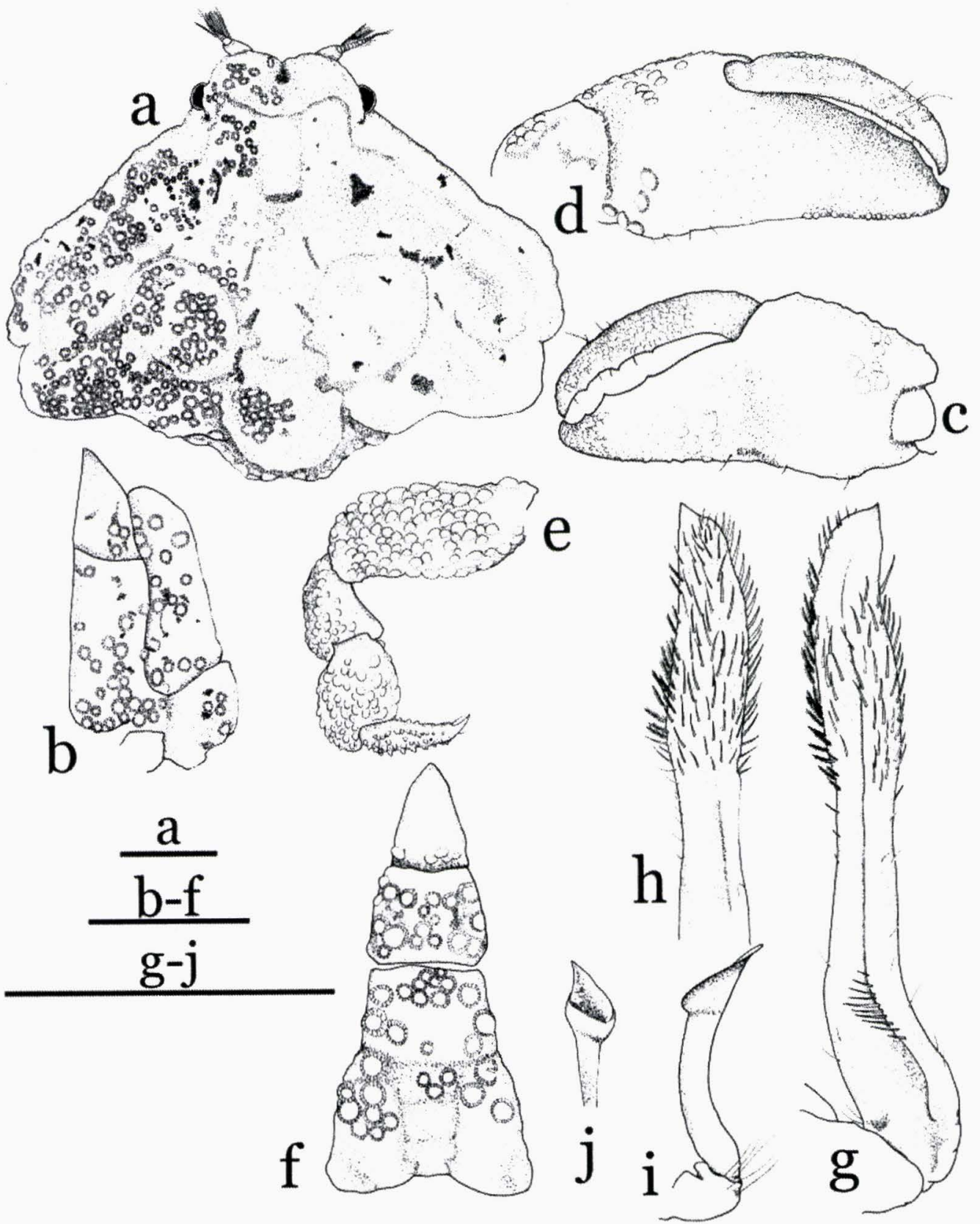

Fig. 2. Alox uru, new species. Holotype, male, CW $5.8 \mathrm{~mm}$ (CBM-ZC 8906).

a, carapace, dorsal view; b, third maxilliped, left; c, chela, left, outer view; d, chela, left, inner view; e, first ambulatory leg, left; f, abdomen and telson; g, G1, left, ventral view; h, distal part of G1, left, dorsal view; i, G2, left, ventral view; j, distal part of G2, left, distal inner view. Scales, $1 \mathrm{~mm}$. 


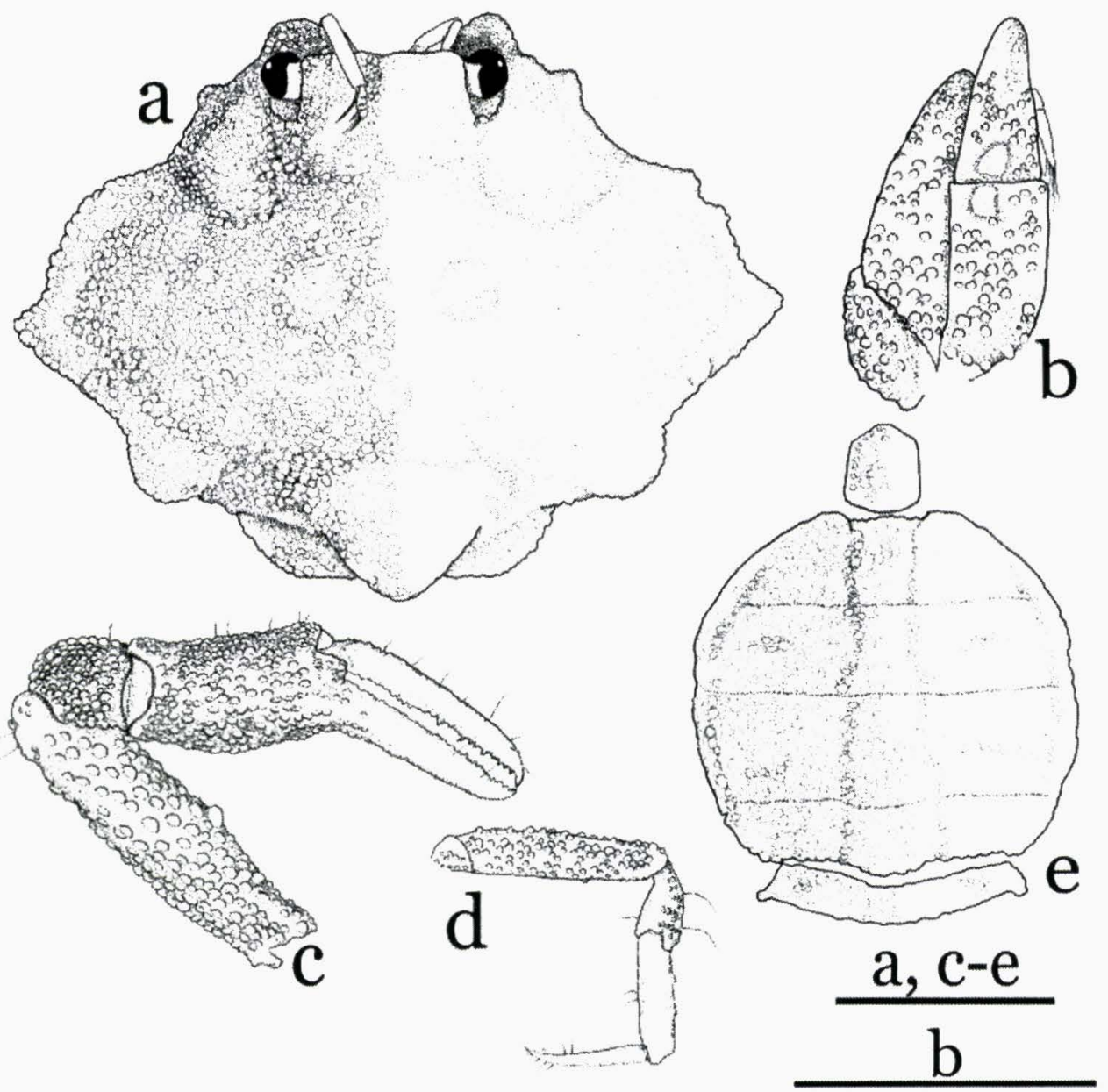

Fig. 3. Ebalia stellaris, new species. Holotype, female, CW $3.6 \mathrm{~mm}$ (CBM-ZC 8907).

a, carapace, dorsal view; b, third maxilliped, left; c, chela, left; $d$, first ambulatory leg, right; e, abdomen and telson. Scales, $1 \mathrm{~mm}$.

longer than the carapace length (about 1.5 times). Ebala stellaris, however, differs distinctly from them in the laterally sloping branchial regions (vs. plate like and lateral part upturned) and the intestinal region being continuous with the posterior margin of the carapace (vs. separated from each other by a transverse shelf) (cf. N. lar, Serène \& Soh, 1976: Pl. 1, Fig. C; N. plicata, Sakai, 1976: Pl. 27, Fig. 2; Sakai, 1999: Pl. 6, Fig. B; N. minor, Shen, 1937: Text-figs. 1, 2; Sakai, 1976: Text-fig. 45; Dai et al., 1986: Pl. 7, fig. 4; N. rhomboidalis, Sakai, 1976: Text- fig. 44; Dai et al., 1986: Pl. 7, Fig. 3; Chen \& Sun, 2002: Fig. 134)

\section{Acknowledgments}

We are grateful to two anonymous reviewers for their comments on this manuscript; and Dr. Hironori Komatsu (National Science Musem, Tokyo) for facilitating to examine comparative specimens. This study was partially supported by the 21st Century COE Program of the University of the Ryukyus 


\section{Literature Cited}

Adams, A., \& White, A., 1848, 1849. Crustacea. In: A. Adams (ed.), The Zoology of H. M. S. Samarang; under the Command of Captain Sir Edward Belcher, C. B., F. R. A. S., F. G. S. During the years 1843-1846: 1-66, pls. 1-13. Part I (pp. 1-32, pls. 1-6), 1848; Part II (pp. 33-66, i-vii, pls. 7-13), 1849., Reeve, Benham, \& Reeve, London.

Balss, H., 1915. Die Decapoden des Roten Meeres II. Anomuren, Dromiaceen und Oxystomen. Expeditionen S. M. Schiff "Pola" in das Rote Meer. Nördliche und Südliche Hälfte, 1895/96-1897/98, Zoologische Ergebnisse XXXI. Denkschriften der kaiserlichen Akademie der Wissenschaften in Wien, mathematisch-naturwissenschaftliche Klasse, 92: 1-20.

Chen, H.-L., \& Sun, H.-B., 2002. Fauna Sinica. Invertebrate vol. 30. Arthropoda: Crustacea: Brachyura: Marine Primitive Crabs. xiii +597 pp. +16 pls., Science Press, Beijing. (In Chinese)

Dai, A.-Y., Yang, S.-L., Song, Y.-Z., \& Chen, G.-X., 1986. Crabs of Chinese Seas. xvii+642 pp., Ocean Press, Beijing. (In Chinese)

Fabricius, J. C., 1793. Entomologia Systematica Emendata et Acuta. Secundum Classes, Ordines, Genera, Species, Adjectis Synonymis, Locis, Observationibus, Descriptionibus, 2 : viii +519 pp. +8 pls., Impensis Christ. Gottl. Proft., Hafniae.

- 1798. Supplementum Entomologiae Systematicae. 572 pp., Proft \& Storch, Hafniae.

Herbst, J. F. W., 1804. Versuch einer Naturgeschichte der Kraben und Krebse nebst einer Systematischen Beschreibung ihrer Vershiedenen Arten, 3(4): 49 pp. + pls. 59-62. Lange, Berlin.

Ihle, J. E. W., 1918. Die Decapoda Brachyura der "Siboga"-expedition. III. Oxystomata: Calappidae, Leucosiidae, Raninidae. Siboga Expeditie Monogr., 39b2 (livre 85): 159-322.

Komatsu, H., \& Takeda, M., 1999. A new leucosiid crab of the genus Nursia from the Ryukyu Islands. Bulletin of the National Science Museum, Tokyo, Series A, 25: 59-64.

$\longrightarrow, \&-$, 2003. A new genus of leucosiid crabs (Crustacea, Decapoda, Brachyura) from the Red Sea. Zoosystema, 25: 413-423.

Leach, W. E., 1817. The Zoological Miscellany, Being Descriptions of New or Interesting
Animals, Illustrated with Coloured Figures, Engraved from Original Drawings by R. P. Nodder. London. 3: vi + 151 + pls. 121-149. [not seen]

Marumura, M. \& Takeda, M., 2004. Taxonomic studies on the crabs of the Nagai Collection preserved in the Wakayama Prefectural Museum of Natural History I. Species new to Japan (1). Nankiseibutu, 46: 93-99. (In Japanese)

Miers, E. J. 1879. On a collection of Crustacea made by Capt. H.C. St. John R.N. in the Corean and Japanese Seas. Part I. Podophthalmia. With an Appendix by Capt. H.C. St. John. Proceedings of the Zoological Society of London, 1879: 18-61, pls 1-3.

Montagu, G., 1808. Description of several marine animals found on the south coast of Devonshire. Transactions of the Linnean Society of London, 9: 81-114. (not seen)

Nobili, G., 1905. Diagnoses préliminaires de 34 espèces et variétés nouvelles, et de 2 genres nouveaux de décapodes de la mer Rouge. Bulletin du Muséum d'Histoire naturelle 11: 393-411.

Rüppell, E., 1830. Beschreibung und Abbildung von 24 Arten kurzschwänzigen Krabben, als Beitrag zur Naturgeschichte des rothen Meeres, Gedrukt und in Commission bei Heinrich Ludwig Brönner. 28 pp. +6 pls., H. L. Brönner, Frankfurt.

Sakai, K., 1999. J. F. W. Herbst-Collection of decapod Crustacea of the Berlin Zoological Museum, with remarks on certain species. Naturalists, Tokushima Biological Laboratory, Shikoku University, 6: 1-45, pls. $1-21$.

2004. Crabs of Japan [CD-ROM]. ETI Information Services Ltd.

Sakai, T., 1976. Crabs of Japan and the Adjacent Seas. Kodansha, Tokyo [In 3 volumes: (1) English text, xxix + 773 pp. (2) Plates volume, 16 pp., 251 pls. (3) Japanese text, 461 pp.].

Serène, R., \& Soh, C. L., 1976. Brachyura collected during the Thai-Danish Expedition (1966). Phuket Marine Biological Center Research Bulletin, 12: 1-37, figs. 1-28, pls. 1-8.

Shen, C.-J., 1937. Second addition to the fauna of brachyuran Crustacea of North China, with a check list of the species recorded in this particular region. Contributions from the Institute of Zoology, National Academy of Peiping, 3: 277-312.

Stimpson, W., 1858. Crustacea Oxystomata: Prodromus descriptionis animalium evertebratorum, quae in Expeditione ad Oceanum 
Pacificum Septentrionalem, a Republica Federata missa, Cadwaladaro Ringgold et Johanne Rodgers Ducibus, observavit et descripsit. Pars VI. Crustacea Oxystomata. Proceedings of the Academy of Natural Sciences of Philadelphia, 10: 159-163.

Takeda, M., 1995. A new leucosiid crab, Arcania uenoi, from the Ryukyu Islands. Special Bulletin of the Japanese Society of Coleopterology, 4: 151-155.

, 1977. Crabs of the Ogasawara Islands, V. A collection made by dredging. Memoirs of the National Science Museum, 10: 113-140.

, \& Nakasone, Y., 1991. Three leucosiid crabs of the genus Philyra from Okinawa, the Ryukyu Islands, with description of a new species. Bulletin of the National Science Museum, Series A, Zoology, 17: 19-24.

Tan, C. G. S. \& Ng, P. K. L., 1993. Praosia puncta$t a$, a new genus and species of mangrove leucosiid crab (Decapoda, Brachyura) from
Singapore. Crustaceana, 64: 40-47.

\&,- 1995 . A revision of the IndoPacific genus Oreophorus Rüppell, 1830 (Crustacea: Decapoda: Brachyura: Leucosiidae). In B. Richer de Forges, (ed.), Les fonds meubles des lagons de NouvelleCalédonie, Études et Thèses, volume 2. ORSTOM, Paris: 101-189.

Weber, F., 1795. Nomenclator entomologicus secundum Entomologian systematicam ill. Fabricii adjectis speciebus recens detectis et varietatibus. viii +172 pp., Chilonii and Hamburgi.

Address: (TN \& PKLN) Department of Biological Sciences, National University of Singapore, 14 Science Drive 4, Singapore 117543, Republic of Singapore.

E-mails: (TN) dbstn@nus.edu.sg; (PKLN) dbsngkl@nus.edu.sg 